\title{
Corporate social responsibility through the library for educational facilities
}

\author{
Putut Suharso ${ }^{*}$, Andri $\mathrm{Yanto}^{2}$, Asep Saeful Rohman ${ }^{2}$, Riah Wiratningsih ${ }^{3}$, and Rahmat \\ Setiawan Saefullah ${ }^{4}$ \\ ${ }^{1}$ Department of Library and Information Science, Diponegoro University, Jl. Prof. H. Soedarto SH, \\ Semarang 50275, Indonesia \\ ${ }^{2}$ Department of Library Science, Padjadjaran University, Jl. Raya Bandung-Sumedang km 21 Jatinangor \\ 45363, Indonesia \\ ${ }^{3}$ Librarian in Sebelas Maret University, Jl. Ir. Sutami 36A, Surakarta 57126, Indonesia \\ ${ }^{4}$ Department of Library Science, Sebelas Maret University, J1. Ir. Sutami 36A, Surakarta 57126, \\ Indonesia
}

\begin{abstract}
This study aims to analyze the role of companies through social responsibility programs in the field of education in improving community literacy. Companies get social benefits when making libraries as their program targets, because libraries are public spaces frequented by many people. The research method used is explorative qualitative research with a case study approach in various libraries in the Surakarta region. This research was designed in accordance with the paradigm of cultural studies on current issues in village level libraries with various problems. Data validity was tested by triangulation techniques involving key informants in the study area. The results of the study describe the function of the library as a learning center, library in supporting the community literacy movement, and CSR in the library. Cooperation between libraries and companies is mutually beneficial cooperation. For village libraries, they will get donations of funds and infrastructure to develop libraries. As for companies by contributing to village libraries, the company has fulfilled its legal obligations and the company's products or services are better known by the community and builds a positive image of the company.
\end{abstract}

\section{Introduction}

Education is an investment, through education an intelligent community will be formed that is able to overcome the problems leading to a better life. Education does not have to be formally interpreted but can be taken through non-formal and informal channels. Talking about education, one can get it through the library as a place to access information or knowledge. Therefore the existence of libraries must be the center of community activities and of course to get the quality of education needs to be supported by an adequate library in terms of collections, facilities and infrastructure, human resources [1]. To get to the sustainability of libraries in carrying out their functions, namely education, it cannot be

\footnotetext{
*Corresponding author: putut.undip@gmail.com
} 
denied that funds are the main capital, then human resources as managers will maintain the sustainability of the role of the library. In this case the library seeks to submit funds through CSR (corporate social responsibility). CSR is part of the company's strategy in building branding that the company exists and takes part in the education sector. Establishing partnerships with stakeholders is important to mobilize the sustainability of the library program.

The research conducted by Slabbert [2] in the last era of this understanding of strategic management in a company continues to grow, not just controlling the market (customers), but also controlling stakeholders. Stakeholders have a role that determines the survival of the company. Between consumers, the environment and natural resources as a single unit that supports each other in a company management system. If there is a disturbance arising from these external factors, it can even stop the company's operations. The company's image will be better in the eyes of the community if it can show its responsibility and concern for the external environment. The existence of the above phenomenon causes the business world to experience a shift in orientation, namely from shareholders to stakeholders. Corporate social responsibility is needed to maintain harmony between the company and the surrounding environment.

The obligation to implement CSR in Indonesia is contained in Law no. 40 of 2007 concerning Limited Liability Company article 74 which states that companies that carry out business activities in the field/related to natural resources must carry out social and environmental responsibilities. The obligation to implement CSR is also applied to companies that invest in Indonesia as stipulated in Law Number 25 of 2007 concerning Investment as stipulated in Article $15 \mathrm{~b}$, namely the obligation to carry out corporate social responsibility. The implementation of CSR which is initially voluntary to fulfill the obligations of companies that are not related to the strategy and achievement of long-term goals, becomes a strategic activity that has a relationship with the achievement of the company's goals in the long term [3]. This is because there are many benefits of implementing CSR correctly and consistently. Chernev and Kotler [4] states that there are benefits that can be obtained by the company by carrying out these strategic activities in CSR activities. The activity has a number of elements, namely continuous and sustainable, community empowerment community, and two-way communication. The implementation of corporate social responsibility is believed to improve company performance, where investors tend to invest in companies that carry out CSR activities.

The existence of libraries in Indonesia at this time is not fully supported by regulations that are fully siding to be able to carry out library service operations. Comparison of the existence of public libraries in Indonesia and abroad certainly has a fairly high gap [5], [6]. Libraries as non-profit institutions and supporting facilities can be what causes the government/institution and people to be able to play an active role. But on the other hand the existence of the library is needed by people who need information and who need a place to study for free [7]. Government policies that require companies to implement CSR programs are a good step for library institutions to attract attention for companies to channel assistance for the sustainability of a library. Professional library management supported by various parties through the provision of space or buildings, facilities and infrastructures, as well as proper wages to the library manager is the initial standard for the existence of an independent library in providing information services.

\section{Research methods}

In this study using explorative qualitative research methods with a case study approach [8], [9] in several village level libraries in the Solo Raya area. This study was designed in accordance with the paradigm of cultural studies on current issues in libraries, especially in 
village level libraries with various points of view [10]. Data obtained from observations to several village libraries and reading parks. Literature study was carried out through local newspaper publications and field work practice reports from library students at Sebelas Maret University. Retrieval of data from informants for several people involved in library activities. Data validity was tested by triangulation techniques involving key informants in the Solo Raya area.

Determination of the research location in the area of ex Surakarta Residency or better known as Solo Raya which consists of the City of Surakarta, Karanganyar regency, Sragen regency, Sukoharjo regency, Wonogiri regency, Boyolali regency, and Klaten regency. Data collection used purposive sampling technique with 15 village libraries from four city districts in the Solo Raya region. In choosing 15 village libraries because they have become part of the CSR program in the library.

The purpose of this study could provide descriptive informative explanations [11] related to the role of libraries in the field of education, especially libraries in improving community literacy, and CSR programs in libraries. Companies get social benefits when making libraries as their program targets, because libraries are public spaces that are often visited by the community.

\section{Result and discussion}

\subsection{The library is the center of learning in the community}

The library is an information and science center that should have an active role in educating and empowering the community. Empowerment is meant is how to make the library as a center of activity in which the community can really feel the benefits, so as to improve their quality of life. According to Bradely, the activities in the library are an important part in supporting the SDGs program from UNESCO [12]. In the UN 2030 Agenda [13] access to information by the public is part of the target of the Sustainable Development Goals 16: Promoting government activities and inclusive programs for sustainable development, providing access to information for all levels of society and building effective, responsible institutions at all levels: Goal 16.10: Ensure access to information by the public is protected into fundamental freedoms Changing our world: Agenda 2030 for Sustainable Development through Culture (target 11.4) and ICT (target 5b, 9c, 17.8) have become part of education in the SDGs.

The development of information technology and media at any time is growing rapidly, almost unstoppable. Library institutions must be able to adjust to current technological developments [14]. But also did not completely abandon the services that lay was done such as circulation services in the presence of books, magazines and newspapers. Because we believe that the source of information in the form of physical reading material is still useful for the future generation of the nation. The presence of technology tools we believe will make it easier to service and organize libraries. Especially for example when the library becomes an information technology-based community learning center, it will certainly make it easier to find information for users. Learning facilities for using internet media have been carried out in several libraries in Surakarta. Through training to the public who attend trainings held by the library. By providing such training, providing community capacity building through library services can bring creativity and innovation in the community [15]-[17].

With all the limitations, the library manager has created information service services. Not all places in village libraries have their own buildings as learning places, some use unused buildings such as unoccupied houses and use unused parts of school buildings. 
There are also those who use public security posts in the daytime used for libraries, at night security posts are used. The source of information served is self-help from library managers and the surrounding community. As a place of learning like a library community, it also means not only as a gathering place for books or information, libraries now have to develop to make information easily accessible to the public, especially accompanied by the rapid development of ICT. Therefore, when the library has been set up to not only be a place to store information but also be used as a place to learn like a community by utilizing information and ICTs in the library.

One of the libraries closest to the community is the village library. The village library must be able to make innovative services, one example is the training to make several products from using information sources in the library. Activities like this can be done in the village library by utilizing the communities in the village, such as Karang Taruna, PKK Programs, Posyandu and others. Village libraries can also collaborate with several agencies related to training activities held by or requesting company assistance by utilizing CSR programs.

\subsection{CSR in the library}

The library is a source of information that is close to the community. a gathering place for people of all ages ranging from teenagers and even parents. So it is appropriate if the library is interested by some companies to be used as a place for the implementation of CSR programs for them. As Komariah said [18] that the library is a public service area that is often visited by the community, so that the public will see and pay attention to the logo or corporate identity that appears in the library, and it is expected that the public will know the donations given by the company to the library.

Assistance provided by the company through CSR programs is very helpful for libraries ranging from assistance in collection collection, adding better facilities, providing information technology devices, even to library management training. One successful program is PerpuSeru. The PerpuSeru program began in November 2011, is a library development program supported by the Coca-Cola Foundation Indonesia (CCFI) and the Bill \& Melinda Gates Foundation. The program aims to make the library a center of learning and community activities based on information and communication technology, with the aim of having an impact on improving the quality of life of the community. Until now the PerpuSeru program has been in 18 provinces, 104 District libraries, 768 Village libraries and has provided economic and social impacts on the community. The National Library of the Republic of Indonesia supported by BAPPENAS began replicating PerpuSeru in 60 district libraries in 2018. The implementation of CSR programs in the Surakarta area was in the form of providing physical assistance to library facilities and training assistance for library managers. Physical assistance facilities provided include: a notebook, three educational games and a camera. Training assistance includes: work planning training, excellent service training and community involvement, information technology training and promotion. CSR activities of several companies in various fields, one of which is related to the field of village libraries, the company contributes to bookshelves, funds for personal village library managers who follow technical guidance, competitions and others.

During its journey, the PerpuSeru program has reached around 14 million people who access library services. A total of 2,300 district/city library staff and supporter libraries have been trained in library development strategies, 300 facilitators have been trained and ready to encourage library development in the district to the village, and 65 national trainers have been trained and ready to facilitate library transformation nationally [19] In addition, the Firefly application for the Library management information system has been 
implemented in 53 district/city libraries and in the next 100 village/TBM libraries will be integrated with the library information system management application program- INLISLite from the National Library of Indonesia.

The Solo Raya area that gets PerpuSeru program are Karanganyar, Boyolali, Klaten, and Sragen. Village library in four regency that received assistance from the Perpuseru an increase in the quality of its services and information technology. Because the PerpuSeru program provides training for library managers and provides computer assistance. Several village libraries in the Solo Raya region that get the Perpuseru CSR program succeeded in increasing the quality of life of the comunity. Like Mrs. Tri W. Hastuti became an entrepreneur thanks to the services of the Mojorejo village library that provided entrepreneurial training. And Mrs. Siti Juariah who received internet training at the Karangtalun library so that she could improve her business promotion. Overall the presence of PerpuSeru by cooperating with village libraries in the Solo Raya area was very beneficial, especially in relation to the use of information by village communities, the community was very pleased with the CSR program. So that it has an impact on increasing the number of people visiting the village library which is a partner of PerpuSeru.

Seeing what the company has given the library through its CSR program certainly has an impact on increasing the image of the company in the eyes of the community. The community does not consider companies that carry out CSR programs to only take advantage, but also provide assistance to the community. Some companies have made libraries as CSR targets such as PT HM Sampoerna Tbk. with Sampoerna Corner, Bank Niaga with its mobile library, Bank Indonesia Corner, PT Pos Indonesia, PT. Pertamina Tbk, PT. Telkom Tbk, the Coca Cola Foundation with several libraries it has built, etc. One of the successful CSR programs was the success of PerpuSeru, which attracted the government's attention to the very strategic role of libraries, Bappenas encouraged the library to become a pioneer of the literacy movement to improve people's welfare. In 2015, Bappenas launched a policy of transforming library services based on social inclusion. This policy is strengthened through the 2019 Government Work Plan (RKP- Rencana Kerja Pemerintah), by making literacy for welfare as one of the priority activities to support national priorities for human development.

\subsection{The library supports the community literacy movement}

The government provides regulatory support and budget politics to the Literacy Movement. The existence of the library as an institution that has the capacity for this literacy movement program. The Literacy Movement in Indonesia is handled by the National Library and the Ministry of Education and Culture. Since 2001 the National Library has launched the Reading Interest Correctional Movement (GPMB- Gerakan Pemasyarakatan Minat Baca) in all provinces and districts/cities in Indonesia. While the Ministry of Education and Culture through Dikmas Directorate General of PAUD 2015 also drives family literacy in the context of empowering families to increase children's reading interest. At the same time, the Directorate General of Primary and Secondary Education develops the School Literacy Movement to improve the reading power of students and the Agency for Language Development and Development drives national literacy by publishing supporting books for students based on local wisdom.

Information literacy is an important skill in the search for knowledge by the community [20]. The basic concepts of literacy include realizing when information is needed and can be found efficiently, evaluated, used effectively, and clearly communicated [21]. Library managers can provide training and guidance to users to be able to act wisely in receiving information, so that the information obtained is true and reliable information on the source. At present the community is easily provoked by information that is untrue and hoak, of 
course it will harm individuals and society. Information that is susceptible to enter the community and is not right certainly makes discomfort in the community especially the issue of sara (ethnicity, religion, race and intergroup).

Literacy movements in libraries need to be framed in an integrated national movement and not partial by certain groups. The literacy movement is not only the responsibility of the government, but also the responsibility of all stakeholders including the business world, universities, social organizations, literacy activists, parents, and the community. Therefore, public involvement in every literacy activity becomes very important to ensure the positive impact of the nation's competitiveness improvement movement.

\section{Conclusion}

The implementation of the CSR program in a library at this time is highly expected by the library manager. Limited facilities and infrastructures in library service operations are greatly affected by performance and visitor visits to libraries. Collaboration between libraries and companies through CSR programs is mutually beneficial cooperation, for libraries will get donations of funds and infrastructure to develop libraries. The company contributing to the library means that the company has fulfilled its obligations.

\section{References}

1. J.K. Meyers, Addressing SDGs and library relevance by serving the majority: introducing innovative child/youth public library services in Zambia (2016)

2. Y. Slabbert, Communication 42, 2, 253-275 (2016)

3. K. Sriramesh, C. Ng, DESIDOC J. Libr. Inf. Technol. 33, 1, 5-6 (2013)

4. A. Chernev, P. Kotler, Strategic Marketing Management, 8th Edition (Cerebellum Press, Chicago, 2014)

5. A. Galluzzi, Libraries and Public Perception: A Comparative Analysis of the European Press, 1st ed. (Chandos Publishing, Oxford, 2014)

6. H. Gong, A.C.A. Japzon, C. Chen, Journal Econ. Soc. Geogr. 99,1, 65-83 (2008)

7. H. Jochumsen, D. Skot-Hansen, C.H. Rasmussen, Int. J. Cult. Policy (2015)

8. L. Stenhouse, Soc. Sci. Inf. Stud. 1, 4, 221-230 (1981)

9. M.Q. Patton, Qualitative Research \& Evaluation Methods: Integrating Theory and Practice (SAGE Publications, California, 2015)

10. P. Saukko, Doing Research in Cultural Studies: An introduction to classical and new methodological approaches (SAGE Publications, London, 2003)

11. P. Bazeley, Qualitative Data Analysis: Practical Strategies (SAGE Publications, Los Angeles, 2013)

12. F. Bradely, IFLA ALP Build. Better Libr. Communities, 40 (2012)

13. M.V. Bertolini, "Libraries, Development and the United Nations 2030 Agenda: How do libraries further development," https://www.ifla.org/libraries-development

14. M. John, K. Lisa, Inf. Technol. Libr. 18, 2, 78 (1999)

15. P. Suharso, B. Sudardi, S.T. Widodo, S.K. Habsari, IOP Conf. Ser. Earth Environ. Sci. 116, $12002(2018)$

16. P. Suharso, B. Sudardi, S.T. Widodo, and S.K. Habsari, E3S Web Conf. SCiFiMaS 2018 47, 7005, 1-6 (2018)

17. P. Suharso, S. Sarbini, E3S Web Conf. SCiFiMaS 2018 47, 7004, 1-6 (2018)

18. N. Komariah, Komun. Inf. 8, 1,13-26 (2009)

19. V. Mahrizal, PerpuSeru Coca-Cola Tingkatkan Literasi untuk Kesejahteraan Masyarakat (Jogjakarta, 2018) 
20. A. Yanto, S. Rodiah, E. Lusiana, J. Informasi, Perpustakaan, dan Kearsipan 19, 1, 3945 (2017)

21. UNESCO, Educ. All Glob. Monit. Rep. 147-159 (2006) 